\title{
Reviewing and Implementing of Cracker Craftsmen Towards Healthy Products with Innovating Various Flavors (Change Bleng to STPP)
}

\author{
Sri Hartini ${ }^{1}$, Ari Budi Kristanto ${ }^{2}$, Yeterina Widi Nugrahanti ${ }^{2}$, Linda Ariany Mahastanti ${ }^{2}$ \\ ${ }^{1}$ Chemistry Department-Faculty of Science and Mathematics, Universitas Kristen Satya Wacana, Salatiga, Indonesia \\ ${ }^{2}$ Faculty Economy and Bussiness, Universitas Kristen Satya Wacana, Salatiga, Indonesia
}

Email address:

dec1arantius@yahoo.com (S. Hartini),sri.hartini@staff.uksw.edu (S. Hartini)

\section{To cite this article:}

Sri Hartini, Ari Budi Kristanto, Yeterina Widi Nugrahanti, Linda Ariany Mahastanti. Reviewing and Implementing of Cracker Craftsmen Towards Healthy Products with Innovating Various Flavors (Change Bleng to STPP). Social Sciences. Vol. 8, No. 4, 2019 , pp. $185-189$. doi: $10.11648 /$ j.ss.20190804.16

Received: February 16, 2019; Accepted: March 20, 2019; Published: August 15, 2019

\begin{abstract}
Tuntang Village cracker craftsmen in Semarang Regency must answer the challenges in developing healthy products and supporting cracker fans. The culture of adding additives make chewy ingredients which at the last time makes crackers when eaten is considered to be one of the stages of the process that must be done. Bleng is a choice for additive material because prices are cheap and easy to buy on traditional markets. Chronic health threats for consumers due to additives in material adding have become neglected by cracker craftsmen. One of the causes is the characteristics of cracker craftsmen who mostly have low levels of education but have a long business experience. Therefore, it is necessary to carry out a strategy of proper knowledge transfer process among cracker craftsmen through laboratory analysis evidence associated with the resulting health impacts and a persuasive approach to encourage transfer of safer than Borax-rich bleng with STPP (Sodium Tripolyphospate). In addition to awareness-raising of additive material also carried out taste diversification counseling so that it can increase sales value. Price changes occur from crackers using bleng additive from Rp. $13,000 / \mathrm{kg}$ to $\mathrm{Rp}$. 35,000/Kg as healty and various taste choices of products.
\end{abstract}

Keywords: Cracker Craftmen, Crispy, Additional Material, Healthy Cracker

\section{Introduction}

The quality of crackers can be assessed using several parameters, namely based on organoleptic, physicochemical, and microbiological. Volume and crisp development is a cracker quality factor that influences consumer acceptance which is seen organoleptically [1]. In order to meet market needs, especially crackers that can expand and crisp when eaten, almost all crackers provide additives in the manufacturing process. The comfort sticky maker additive and cracker developer that is easily found in traditional markets with low prices is bleng or often known as borak, cetitet, puli medicine or gendar medicine.

Crackers in the Tuntang area of Semarang Regency produce various choices of crackers ranging from soybean crackers and terung and garlic flavour as well as shrimp flavored crackers with eye-catching colors (Figure 1 a-d).

\subsection{Tuntang's Crackers Producers}

Result study of [2] shown that their small industries were mostly started from the family, the fathers as owners and other family members such as wives, sons, and daughters assist in the management and production processes. In Tuntang, Semarang Regency, there are two villages that almost all of their livelihoods are from the cracker business, i.e. Gading and Praguman, with a total enterpreneur of approximately 107. Crackers which are produced can be divided into two, namely soybean crackers and cassava crackers. The types of cracker business conducted crackers have two different kinds of crackers, that are by using raw soybeans and cassavas. Almost all of the entire population of those villages (Gading and Praguman) are crackers enterpreneurs.

At the beginning observation was performed on 2013, all 
the crackers producers adding additive materials were bleng. The process involving the role of bleng has been carried out for generations without knowing the chronic health effects of bleng content in the consumer's body. Manufacturers with all the limited knowledge of the effects of bleng only think about how their cracker products are liked and sell well.

One more thing that is noted at the outset is sanitation

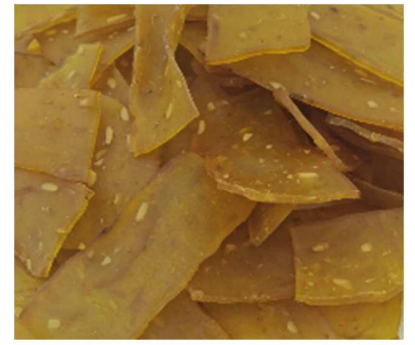

a. Soybean crackers

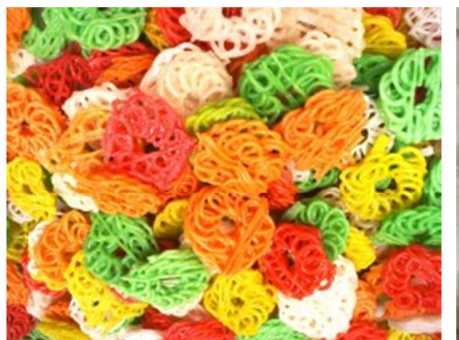

b. Terung crackers during the cracker manufacturing process and the final action in drying. Most of the cracker producers drying directly on the ground are only covered by plastic or woven bamboo, even the drying position is also carried out on the roadside which is loaded with vehicles passing by. This causes the quality of the crackers produced to be questionable for their consumers' health.

Figure 1. Various cracker products.

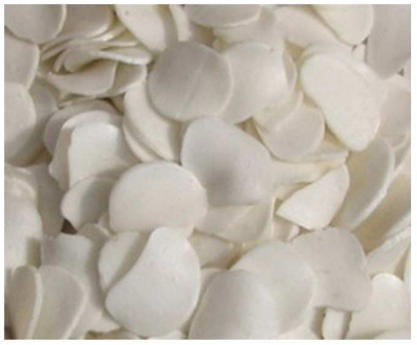

c. Garlic flavored crackers

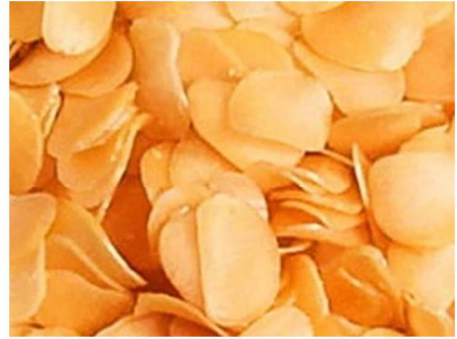

d. Shrimp flavored crackers

\subsection{Bleng and STPP (Sodium Tripolyphospate)}

Bleng and STPP (Sodium Tripolyphospate) as Shown on Figure 2.

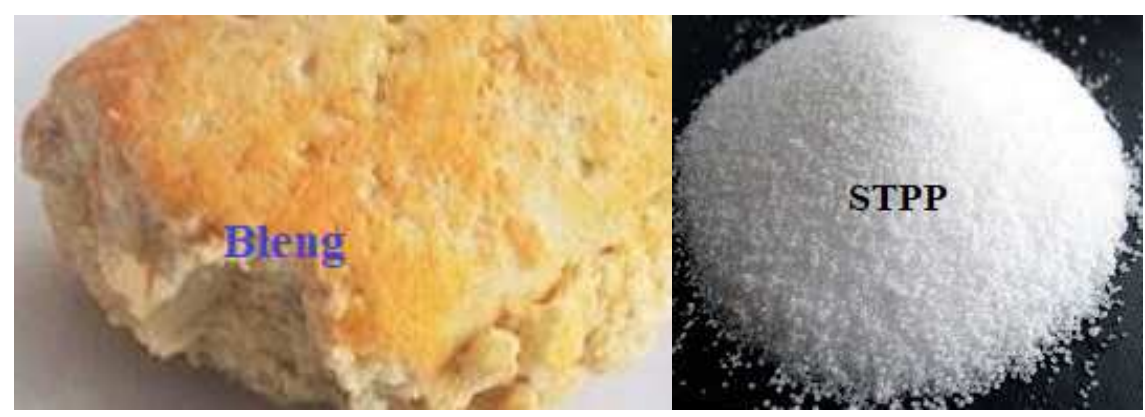

Figure 2. Sticky and cracker maker of crispy.

\section{Bleng}

The chemical formula bleng or borax is $\mathrm{Na}_{2} \mathrm{~B}_{4} \mathrm{O}_{7} 10 \mathrm{H}_{2} \mathrm{O}$. Bleng is a high concentration mineral salt mixture [3]. The shape is long and has a rather yellow color. This substance is an impure form of boric acid, while its pure form is widely known as borax. In Indonesia, Bleng has been produced since 1700 in the form of bleng water. This liquid is usually produced from salt fields or mud craters. The use of bleng in food aims to provide a distinctive aroma and flavor while filling and making the mixture expand. The texture and appearance of food is good. Bleng makes crackers gendar / karak / puli bloom when fried and feels crunchy [4].

Long-term consumption of borax has very dangerous effects such as circular depression, cyanosis, convulsions to coma $[5,6]$. Some animal studies report borax with a concentration of 6,700 ppm can reduce sperm quantity and testicular atrophy resulting in male infertility. In addition, it can also cause disorders of the central nervous system, cutaneous abnormalities and growth retardation and toxicity to the embryo or fetus [7].

The government has banned the use of borax as food ingredients as of July 1979, and was established through the Decree of the Minister of Health of the Republic of Indonesia

\section{No. 733/Menkes./Per/IX/1988.}

STPP (Sodium Tripolyphospate)

STPP is a sodium salt of triphosphoric acid that has the appearance of white crystal powder. It is odorless and is water soluble. STPP mampu menambah citarasa, memperbaiki tekstur, mencegah terjadinya rancidity (ketengikan), dan meningkatkan kualitas produk akhir dengan mengikat zat nutrisi yang terlarut dalam larutan garam seperti protein, vitamin, dan mineral [8].

\section{Implementation Method}

The location of the activity is in the village of Tuntang in Semarang Regency, Central Java, Indonesia.

\subsection{Facilities and Infrastructure}

\subsubsection{Materials}

The initial ingredients used are flour, cassava flour (tapioca), soybeans, and complementary spices, such as onions, white and coriander powder and other complementary materials, such as sticky maker given bleng. Healthy products which are then made are bleng replaced with STPP (Sodium Tripolyphospate) and various flavored 
enrichments. The tools needed are plastic basin, jumbo pan, stove, grinder, stirrer and baking sheet.

\subsubsection{Drying}

Drying which was originally carried out on the ground with plastic sheets or woven bamboo is then made a recommendation with a distance of about $1 \mathrm{~m}$ from the ground surface.

\subsection{Training Objectives}

The action review activity is packaged in the form of community empowerment with persuasive methods in its initial form, opening up a discourse on product competition and market needs for the availability of crackers. The cracker producer community was also brought to the thought of the importance of healthy products and did not pose a threat related to the content of crackers originating from additive materials in the process. A healthy process with a hygienic production site is also one of the targets of awareness.

The steps to carry out the action review on the cracker producer community are:

a. Participants are given the opportunity to get to know each other's products in terms of the materials used and the health threat side.

b. Participants were brought to discuss the scientific thinking about the threats that arise from additional materials for making crackers.

c. Participants were invited to look at the presentation of laboratory analysis results from existing products.

d. Participants are brought to the choice of substitutive material that has the same function as springy maker and developer.

e. Participants immediately make crackers with substitute ingredients for cracker production.

f. Participants at the same time become a tester of ready- to-eat products that contain healthier substitute additives.

g. Participants are provided with the motivation to have a visionary spirit of vision and visionary vision to answer the challenges ahead.

\subsection{Crackers Sample Laboratory Analysis for Original Any Crackers Product with Bleng}

Laboratory analysis was carried out on samples taken randomly (collected 8 types of crackers) from cracker producers in Tuntang, as a control was crackers with famous brand $\mathrm{X}$. The parameters tested were several nutritional value content such as carbohydrates with Luff-Schoorl method, proteins, soluble fibers and indicators of borax content [912].

\subsection{Monitoring After Empowerment of 2013}

The length of observation of the changes that occur is done after community empowerment joined in cracker producers in Tuntang is 5 years from 2013. Observation is more focused on innovative products that allow market expansion not only local but global possibilities, including the choice of sticky and crispy makers, diversification product and packaging invasion and indication of selling value.

\section{Result and Discussion}

\subsection{Quality Original Any Crackers Based on Laboratory Analysis}

The results of the laboratory analysis show that the nutrient content of Tuntang crackers in general is not much different from the crackers produced from famous cracker producers with the initials X (Table 1 and Figure 3).

Table 1. Nutritional Analysis Data.

\begin{tabular}{|c|c|c|c|c|c|c|c|c|c|}
\hline Content (\%) & $\mathbf{A}$ & B & $\mathrm{C}$ & D & $\mathbf{E}$ & F1 & F2 & $\mathbf{G}$ & Control \\
\hline Carbohydrate & 2.8 & 4.5 & 1.5 & 5.3 & 6.6 & 12.5 & 9.1 & 3.0 & 49.6 \\
\hline Protein & 1.8 & 2.2 & 1.7 & 1.9 & 1.9 & 1.9 & 1.9 & 1.7 & 1.8 \\
\hline Lipid & 0.003 & 0.018 & 2.290 & 0.190 & 0.610 & 0.780 & 0.180 & 0.200 & 0.360 \\
\hline Dissolved fiber & 58.5 & 49.8 & 88.5 & 72.8 & 45.1 & 80.3 & 81.4 & 75.3 & 38.0 \\
\hline $\mathrm{pH}$ & 5 & 5.5 & 5.7 & 6.9 & 6.5 & 8.2 & 7.5 & 5.2 & 6.7 \\
\hline
\end{tabular}

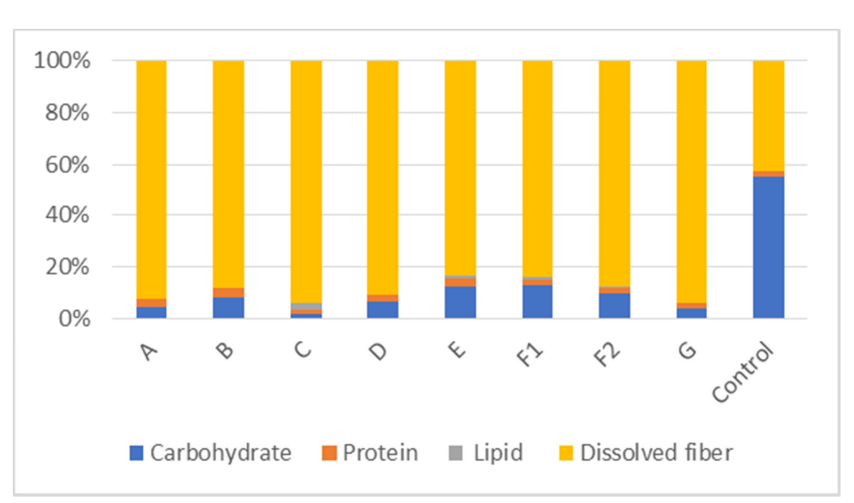

Figure 3. Histogram of Nutritional Analysis.
Data from the analysis show interesting phenomena related to the nutrient content of the sample. Generally, local crackers (Tuntang products) are no less crowded compared to factory crackers with famous brands (X), for the carbohydrate content (49.6\%), in exception. Either protein, lipids or dissolved fiber, Tuntang crackers are actually higher than X.

\subsection{Product After Changing of Sticky Maker with STPP}

Crackers products after replacing the chewy maker from bleng to STPP turned out to produce crackers which had a slightly less salty taste. so it was necessary to add salt. Only the level of crystallization is the same as the development of frying. 


\subsection{Inovation Any Cracker Products on 2019}

Monitoring and evaluating the empowerment of Tuntang cracker producers after 6 years later was very surprising. In addition to quality choices (Bleng or STPP), because there are still many consumers whose purchases are based on price and exclude health (still contain bleng), the choice of flavor is also attractive packaging for cracker products ready for consumption. Figure 4 shows the interesting crackers in the pack presented. Rohayati, one of the producers (Makmur Abadi owner) explained that the producers in Tuntang currently serve a variety of quality and packaging choices [13].

Motivation for producers must always be done especially facing the era of the global market which is currently underway and will continue to grow.

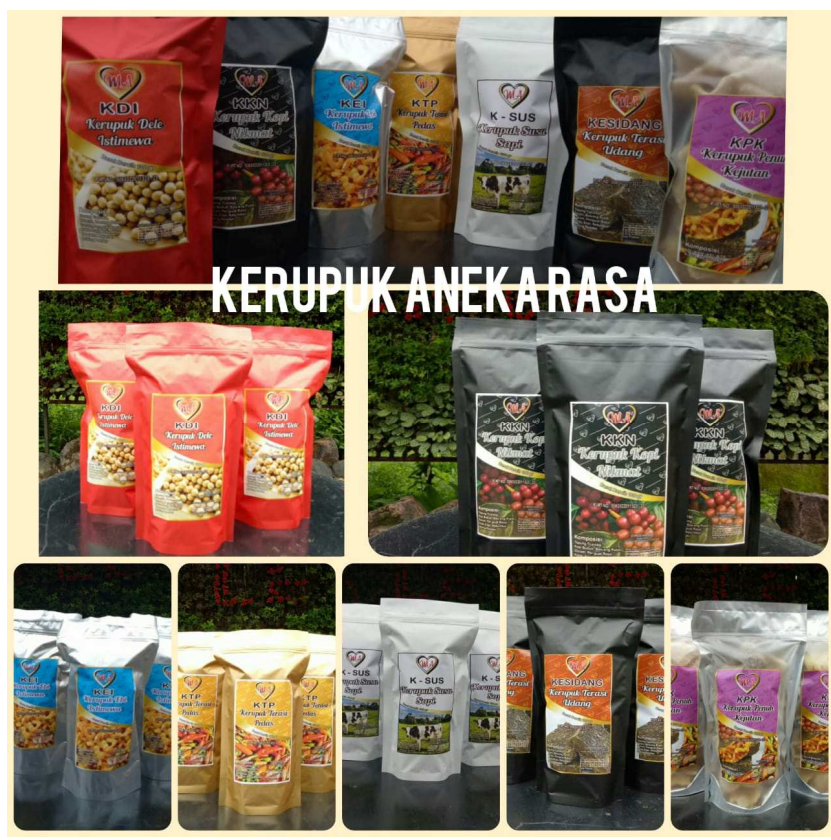

Figure 4. Various flavors of crackers at Makmur Abadi counter-Tuntang [13].

\subsection{Increase in Selling Value}

From the results of direct contact with one of the producers, it was informed that the original soybean crackers with a chewy maker of bleng were sold for Rp. 13,000 / Kg, while with STPP the price can reach Rp. 35,000 / Kg. Products with a choice of various flavors in packs of 1 ounce and ready to eat are weighed at Rp. 12,000 / pack [13].

\section{Conclusion}

The replacement of the chewy ingredients from crackers from Bleng to STPP does not change the taste or expansion of the product. Sanitary patterns during processing and drying affect healthier final products and encourage consumers to prefer cracker products. Increased choice of quality crackers and innovative packaging opens up a wider market and more open prospective export potential.

\section{Acknowledgements}

We wish to thank crackers entrepreneur who are willing to provide the data to aid researchers in making this article. Especially Ms. Erna Rohayati as one of the most progressive and innovative cracker producers developing their crackers and packaging products.

\section{References}

[1] Laiya. N. Rita M. H. dan Nikmawatisusanti Y. 2014. Formulasi Kerupuk Ikan Gabus yang Disubstitusi dengan Tepung Sagu. Jurnal Ilmiah Perikanan dan Kelautan. Volume II. Nomor 2. Lib.unnes.ac.id/5826/1/7569.pdf.

[2] Mahastanti. L. A. Yeterina W. N. and Sri H., 2013. The Model Of Knowledge Transfer of Small and Medium Enterprises In Creating Product Innovation (A Case Study Of Cracker Enterprises In Tuntang. Semarang Regency). International Journal of Business and Management Invention ISSN (Online): 2319-8028. ISSN (Print): 2319 - 801X www.ijbmi.org Volume 2 Issue 11\| November. 2013\| PP. 26-38 www.ijbmi.org.

[3] Pane. I. S. Devi N. dan Indra Chayaya. 2012. Analisis Kandungan Boraks $\left(\mathrm{Na}_{2} \mathrm{~B}_{4} \mathrm{O}_{7} 10 \mathrm{H}_{2} \mathrm{O}\right)$ Pada Roti Tawar Yang Bermerek dan Tidak Bermerek yang Dijual Di Kelurahan Padang Bulan Kota Medan Tahun 2012. https://media.neliti.com/media/publications/14404-IDanalisis-kandungan-boraks-na2b4o 7-10-h2o-pada-roti-tawaryang-bermerek-dan-tidak.pdf.

[4] Detikfood. 2012. Bleng. Bahan Kimia Mirip Boraks Biasa Dipakai untuk Kerupuk. https://food.detik.com/info-kuliner/d1950663/bleng-bahan-kimia-mirip-boraks-biasa-dipakaiuntuk-kerupuk.

[5] See. A. W. 2010. Risk and health Effect of Boric Acid. American Journal of Applied Sciencies 7 (5). 2010. p620-627.

[6] Research Report. 2015. Survey of Boric acid and sodium borates (borax). The Danish Environmental Protection Agency Strandgade 291401 Copenhagen. ISBN no. 978-87-93352-23-0. https://www.ft.dk/samling/20151/almdel/SUU/bilag/106/1581 395.pdf.

[7] Sentra Informasi Keracunan Nasional (SIKerNas). Pusat Informasi Obat dan Makanan: Asam Borat. Badan POM RI. http://ik.pom.go.id. Accessed: February 16, 2019.

[8] Nugraha. E. P. Merkuria K. and Linda K.. 2017. STPP (Sodium tripolyphosphate) As A Substitute Material Solid Bleng in Karak Making with Different Rice Variety. https://ejurnal.unisri.ac.id/index.php/jtpr/article/download/.../1 340 .

[9] Lioe. M. Hanifah N. H. dan Dian. 2017. Perbandingan Metode dan Verifikasi Analisis Total Karbohidrat dengan Metode Luff-Schoorl dan Anthrone Sulfat. http://repository.ipb.ac.id/ handle/123456789/53643.

[10] Janairo. G. C. Marianne L. Leonisa Y. and Julita R.. 2011. Determination of the Sensitivity Range of Biuret Test for Undergraduate Biochemistry Experiments. $e$-Journal of $\begin{array}{llll}\text { Science } \quad \& \quad \text { Technology } & \text { (e-JST). }\end{array}$ https://www.researchgate.net/publication/267722242 Determination of the Sensitivity Range_of_Biuret_Test_for_Undergraduate_Biochemistry_Ex periments. 
[11] Shin. D. 2012. Analysis of dietary insoluble and soluble fiber contents in school meal. Nutr Res Pract. 6 (1): 28-34. Published online 2012 Feb 29. doi: 10.4162/nrp.2012.6.1.28.

[12] B. Srinivasulu. Bhadra D. P. and Murthy P. H. C. 2012. Physico-Chemical Standardization of Tankana (Borax): An
AyurvedicMineral Drug. ISSN: 2277-7695CODEN Code: PIHNBQZDB-Number: 2663038-2IC Journal No: 7725 Vol. 1 No. 62012 Online Available at www.thepharmajournal.

[13] Rohayati. E., 2019. Direct communication. 